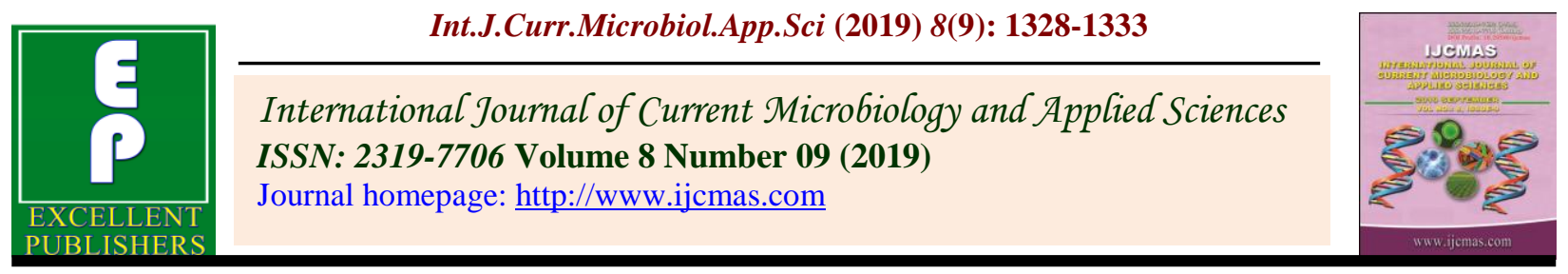

Original Research Article

https://doi.org/10.20546/ijcmas.2019.809.152

\title{
Hydrocyanic Acid (HCN) Estimation during Different Stages of Growth in Gundrijowar (Sorghum vulgare) Fodder Crop
}

\author{
C. N. Jadav, R. B. Makwana*, S. S. Parikh, P. M. Gamit, \\ K. S. Murthy and P. U. Gajabhiye
}

Cattle Breeding Farm, Junagadh Agricultural University, Junagadh- 362001, Gujarat, India

*Corresponding author

Keywords

Gundrijowar,

Hydrocyanic acid

(HCN), Sorgum vulgare, DAS (Day after Sowing).

\section{Article Info}

Accepted:

15 August 2019

Available Online:

10 September 2019

\section{A B S T R A C T}

The present research trial was carried out in kharif and summer season from year 2013-2015 at Cattle Breeding Farm, Junagadh agricultural University, Junagadh, Gujarat. Gundrijowar fodder samples were collected for quantitative HCN (mg/100 gm dry matter) concentration from eight sown plots from 15 DAS (Day after sowing) up to 60 DAS at fortnightly intervals and one more sampling was carried out when Gundrijowar fodder crops exhibit $25 \%$ flowering stage. Result revealed that concentration of HCN ( $\mathrm{mg} / 100 \mathrm{gm}$ dry matter) in Gundrijowar fodder crop in kharif \& summer season decreased significantly $(\mathrm{p}<0.05)$ during the year 2013 and 2015, up to $25 \%$ flowering stage. It was concluded that freshly cut Gundrijowar (Sorghum vulgare) fodder can be fed safely without any poisonous effect to animals at $25 \%$ flowering stage.

\section{Introduction}

Gundrijowar (Sorghum vulgare) is commonly grown single cut variety of sorghum in Saurashtra region of Gujarat. It is nutritious, palatable fodder crops and it can be fed as green, dry or as conserved fodder in the form of silage or hay. Cultivation of sorghum compare to other forage crops is widely practiced due to suitability to wide variation in soil and climatic conditions, its high tolerance to various stresses and having many advantages like high biomass accumulation, quick growth, high dry matter content and wide adaptability besides drought withstanding ability (Reddy et al., 2004).

Sorghum is considered to be a good feed in ordinary conditions but when its normal growth is constrained by drought or imbalanced soil nutrients, hydrocyanic acid (HCN) content may develop to such an extent 
that the toxic level may reach lethal level when fed to animals (Fjell et al., 1991). Cyanide occurs in the leaves of sorghum as cyanogenic glycoside dhurrin. Degradation of dhurrin yields equimolar amount of hydrocyanic, glucose and Phydroxybenzaldehyde (P-HB).

Ruminant animals are very susceptible to $\mathrm{HCN}$ poisoning because environment of rumen is slightly acidic, more water content and microflora present in rumen can rapidly convert cyanogenic glyocosides available in plants to free cyanide gas "Prussic acid poisoning or hydrocyanic acid poisoning (HCN)". Due to ignorance and lack of knowledge, dairy farmers feed freshly cut sorghum from early stages of growth, when cyanide is taken to the body, it's rapidly absorbed and circulated, then it's merged with methemoglobin and forms cyanomethemoglobin. The circulating cyanide inactivates cytochrome oxidase enzyme by binding ferric $(\mathrm{Fe}+++)$ iron which is within this enzyme. Normally the cytochrome oxidase enzyme catalyzes the last step of oxidative phosphorylation.

The enzyme-cyanide complex prevents this task from being performed. Because of that the enzyme can't combine with oxygen and electron transportation becomes inhibited. The patient can't use caloric oxygen and cellular respiration stops immediately. As a result of this process, death occurs due to histotoxic anoxia. The death of animals and even at doses as little as $0.5 \mathrm{gm}$ is sufficient to kill a cow. The risk of HCN toxicity decreases with maturity of the plant, older plants and leaves contain less cyanogenic glycoside (Carlson and Anderson, 2013). Srinivasa et al., (2006) recorded that high $\mathrm{HCN}$ content in the sorghum plant in early growth stage, which decreased with plant maturity. The safe limit of $\mathrm{HCN}$ in green forage for livestock is 500 ppm on fresh weight basis and 200 ppm on dry weight basis (Karthika and Kalpana, 2017). Present experiment was planned to estimate varying levels of $\mathrm{HCN}$ in Gundrijowar (Sorghum vulgare) fodder crop during their growth period to keep dairy farmers informed to feeding to ruminant animals at safe level of $\mathrm{HCN}$.

\section{Materials and Methods}

\section{Experimental Design}

The present research trial was conducted in randomly selected 8 plots (100x100 sq meter sizes) in which Gundrijowar (Sorgum vulgare) fodder crops were cultivated in kharif and summer season from year 2013-2015.

\section{Agro climatic region \& Place of work}

The present research trial was conducted at Cattle Breeding Farm, Junagadh agricultural University, Junagadh, under south Saurashtra agro climatic region, Gujarat, India.

\section{Sampling materials}

Soil samples were collected before starting of trial followed by standard procedure from total 8 selected plots under trail for estimation of Nitrogen, Phosphorus and Potash.

In Cattle Breeding Farm, Junagadh agricultural University, Junagadh, Gujarat, Gundrijowar is sown in summer and kharif seasons.

Hence, samplings were limited only in two seasons. Gundrijowar fodder samples were collected for quantitative $\mathrm{HCN}$ (mg/100gm dry matter) concentration from eight sown plots from 15 DAS (Day after sowing) up to 60 DAS at regularly fortnightly intervals and one more sampling was carried out when Gundrijowar fodder crops exhibit $25 \%$ flowering stage. 
Quantitative estimation of $\mathrm{HCN}$ (mg/100 gm dry matter) concentration in Gundrijowar (Sorgum vulgare)

Quantitative estimation of $\mathrm{HCN}(\mathrm{mg} / 100 \mathrm{gm}$ dry matter) was done according to AOAC (1995) as under:

Two gram of green chopped Sorghum sample was taken in a test tube and moistened with distilled water. Few drops of chloroform were added to the contents of the test tube. Sodium Picrate filter paper strips $(1 \times 10 \mathrm{~cm}$ Whatsman filter paper no.1) were prepared by dipping the strips into solution containing 1\% Picric acid and $10 \%$ Sodium Carbonate and air dried. Filter papers were inserted into the test tube containing fodder sample and closed with a rubber cork.

Change in color of filter paper happened immediately after five minutes, however strips were allowed to remain for about six hours in the test tube. Filter paper turned from yellow color to brick red color as per the concentration of $\mathrm{HCN}$. After evaluating qualitatively, filter paper strips were removed from the test tube chopped to small pieces in to another test tube containing $10 \mathrm{ml}$ distilled water.

Filter paper strips were thoroughly mixed in a Cyclomixer and centrifuged at $5000 \mathrm{rpm}$ for 10 minutes and color intensity was read using Spectronic 20 @ $520 \mathrm{~nm}$. Standard curve was prepared by following the above method using Potassium Cyanide.

\section{Observations Recorded}

\section{Soil analysis for Nitrogen, Phosphorus and} Potash

Soil testing was carried out for total 8 selected plots for Nitrogen, Phosphorus and Potash before starting of trial (Table 1).
HCN (mg/100 gm dry matter) concentration in Gundrijowar (Sorghum vulgare)

Concentration of Hydrocyanic acid (HCN$\mathrm{mg} / 100$ gm dry matter) measured at fortnightly intervals from 15 DAS (Day after sowing) up to 60 DAS from Gundrijowar fodder samples from eight sown plots and one more sampling was carried out when Gundrijowar fodder crops exhibit 25\% flowering stage.

\section{Statistical Analysis}

All the recorded data were subjected to statistical analysis by "factorial and completely randomized design" (FCRD) employing one-way analysis of variance as per Snedecor and Cochran (1994).

A p-value of $<0.05$ was considered as significant difference among the treatments groups and the comparison of means were tested as per Duncan's multiple range test (DMRT) described by Duncan (1955).

\section{Results and Discussion}

Concentration of $\mathrm{HCN}(\mathrm{mg} / 100$ gm dry matter) in Gundrijowar fodder crop was decreased significantly $(\mathrm{p}<0.05)$ up to $25 \%$ flowering stage in summer season during the year 2013 and 2015. While in the year 2014 significant decline was up to 60 DAS and the concentration was at par at 60 DAS and 25\% of flowering stage. Pooled data showed similar trend to that of the year 2014 with reference to $\mathrm{HCN}$ concentration (Table 2).

Concentration of $\mathrm{HCN}(\mathrm{mg} / 100 \mathrm{gm}$ dry matter) in Gundrijowar (Sorghum vulgare) fodder crop was declined significantly $(\mathrm{p}<0.05)$ up to $25 \%$ flowering stage in kharif season during 2013 and 2014, respectively. In kharif season of the year 2015, HCN concentration though declined from 15 DAS 
to 45 DAS significantly and it was at par at 60 HCN concentration decline was similar to that DAS and 25\% flowering. In the pooled data, of the year 2015 (Table 3).

Table.1 Nitrogen, Phosphorus and Potash concentrations of Soil (8 plots) selected for thestudy.

\begin{tabular}{|c|c|c|c|c|c|c|c|}
\hline \multirow{2}{*}{$\begin{array}{l}\text { Sr. } \\
\text { No. }\end{array}$} & \multirow[t]{2}{*}{ Plot No. } & \multicolumn{2}{|c|}{$(1: 2.5)$} & \multirow[t]{2}{*}{ O.C.\% } & \multirow{2}{*}{$\begin{array}{c}\text { Nitrogen } \\
\text { kg/ha }\end{array}$} & \multirow{2}{*}{$\begin{array}{l}\text { Phosphorus } \\
\left(\mathrm{P}_{2} \mathrm{O}_{5}\right) \mathrm{kg} / \mathrm{ha}\end{array}$} & \multirow{2}{*}{$\begin{array}{c}\text { Potash } \\
\left(\mathrm{K}_{2} \mathrm{O}\right) \mathrm{kg} / \mathrm{ha}\end{array}$} \\
\hline & & $\mathrm{EC} \mathrm{ds} \mathrm{/m}$ & pH & & & & \\
\hline 1. & $11 / 3$ & 0.28 & 8.15 & $\begin{array}{l}1.02 \\
\text { High }\end{array}$ & $\begin{array}{l}355.0 \\
\text { High }\end{array}$ & $\begin{array}{c}39.49 \\
\text { Medium }\end{array}$ & $\begin{array}{l}110.0 \\
\text { Low }\end{array}$ \\
\hline 2. & $11 / 4$ & 0.25 & 8.2 & $\begin{array}{l}0.81 \\
\text { High }\end{array}$ & $\begin{array}{l}389.0 \\
\text { High }\end{array}$ & $\begin{array}{c}35.39 \\
\text { Medium }\end{array}$ & $\begin{array}{l}99.0 \\
\text { Low }\end{array}$ \\
\hline 3. & $12 / 2$ & 0.37 & 7.97 & $\begin{array}{c}0.99 \\
\text { High }\end{array}$ & $\begin{array}{l}317.0 \\
\text { High }\end{array}$ & $\begin{array}{c}50.27 \\
\text { Medium }\end{array}$ & $\begin{array}{l}320.0 \\
\text { High }\end{array}$ \\
\hline 4. & $12 / 3$ & 0.51 & 7.93 & $\begin{array}{l}0.93 \\
\text { High }\end{array}$ & $\begin{array}{c}279.0 \\
\text { Medium }\end{array}$ & $\begin{array}{c}44.62 \\
\text { Medium }\end{array}$ & $\begin{array}{c}192.0 \\
\text { Medium }\end{array}$ \\
\hline 5. & $12 / 4$ & 0.31 & 7.96 & $\begin{array}{c}0.99 \\
\text { High }\end{array}$ & $\begin{array}{l}622.0 \\
\text { High }\end{array}$ & $\begin{array}{l}67.19 \\
\text { High }\end{array}$ & $\begin{array}{l}386.0 \\
\text { High }\end{array}$ \\
\hline 6. & $14 / 1$ & 0.27 & 8.45 & $\begin{array}{l}0.90 \\
\text { High }\end{array}$ & $\begin{array}{c}299.0 \\
\text { Medium }\end{array}$ & $\begin{array}{c}40.01 \\
\text { Medium }\end{array}$ & $\begin{array}{l}82.0 \\
\text { Low }\end{array}$ \\
\hline 7. & $14 / 2$ & 0.36 & 8.43 & $\begin{array}{c}0.99 \\
\text { High }\end{array}$ & $\begin{array}{l}302.0 \\
\text { High }\end{array}$ & $\begin{array}{c}28.21 \\
\text { Medium }\end{array}$ & $\begin{array}{l}148.0 \\
\text { Low }\end{array}$ \\
\hline 8. & $14 / 3,4$ & 0.33 & 8.18 & $\begin{array}{l}0.90 \\
\text { High }\end{array}$ & $\begin{array}{l}540.0 \\
\text { High }\end{array}$ & $\begin{array}{c}37.44 \\
\text { Medium }\end{array}$ & $\begin{array}{l}121.0 \\
\text { Low }\end{array}$ \\
\hline
\end{tabular}

* From soil composition it is evident that Nitrogen, Phosphorus and Potash concentrations were usual in comparison to other plots in $\mathrm{CBF}$.

Table.2 Concentration of HCN (mg/100 gm dry matter) in Gundrijowar (Sorghum vulgare) fodder crop at different stages after sowing during summer season from 2013-2015.

\begin{tabular}{|c|c|c|c|c|}
\hline Treatment & Summer-2013 & Summer-2014 & Summer-2015 & Pooled \\
\hline 15 DAS & 376.13 & 297.13 & 273.50 & 315.58 \\
\hline 30 DAS & 291.25 & 171.25 & 180.25 & 214.25 \\
\hline 45 DAS & 137.00 & 92.00 & 98.00 & 109.00 \\
\hline 60 DAS & 33.00 & 35.88 & 53.25 & 40.71 \\
\hline $25 \%$ Flowering & 10.25 & 13.50 & 18.63 & 14.13 \\
\hline S.Em. \pm & 7.15 & 12.93 & 9.76 & 19.42 \\
\hline C.D. at $5 \%$ & 20.54 & 37.16 & 28.03 & 63.33 \\
\hline C.V.\% & 11.93 & 30 & 22.13 & 20.85 \\
\hline \multicolumn{5}{|l|}{ Year } \\
\hline S.Em. \pm & & & & 15.04 \\
\hline C.D. at $5 \%$ & & & & 49.05 \\
\hline \multicolumn{5}{|l|}{ YXT } \\
\hline S.Em. \pm & & & & 10.22 \\
\hline C.D. at $5 \%$ & & & & 28.70 \\
\hline
\end{tabular}


Table. 3 Concentration of HCN (mg/ 100 gm dry matter) in Gundrijowar (Sorghum vulgare) fodder crop at different stages after sowing during Kharif season from 2013 to 2015.

\begin{tabular}{|c|c|c|c|c|}
\hline Treatment & Kharif-2013 & Kharif-2014 & Kharif-2015 & Pooled \\
\hline 15 DAS & 275.88 & 306.88 & 218.13 & 266.96 \\
\hline 30 DAS & 151.88 & 181.75 & 107.13 & 146.92 \\
\hline 45 DAS & 75.38 & 109.75 & 56.63 & 80.58 \\
\hline 60 DAS & 39.13 & 42.63 & 32.63 & 38.13 \\
\hline 25\% Flowering & 18.38 & 14.38 & 17.75 & 16.83 \\
\hline S.Em. \pm & 9.95 & 7.55 & 8.15 & 11.86 \\
\hline C.D. at $5 \%$ & 28.58 & 21.69 & 23.42 & 38.67 \\
\hline C.V. \% & 25.09 & 16.29 & 26.67 & 22.16 \\
\hline \multicolumn{5}{|l|}{ Year } \\
\hline S.Em. \pm & & & & 9.19 \\
\hline C.D. at $5 \%$ & & & & 29.96 \\
\hline \multicolumn{5}{|l|}{ YXT } \\
\hline 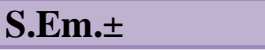 & & & & 8.61 \\
\hline C.D. at $5 \%$ & & & & 24.17 \\
\hline
\end{tabular}

Muthuswamy et al., (1976) reported that HCN content was more at the early stage of crop and it decreased at maturity stage. They found that the HCN content was high 18 days after sowing and decreased gradually up to 53 days in CSH 5 type of hybrid variety of sorghum. Chaturvedi et al., (1994) reported that HCN content decreased significantly from 65 days after sowing to gain maturity stage. Wheeler $e t$ al., (1990) also reported decrease in $\mathrm{HCN}$ content with plant age in sorghum.

It could be concluded that irrespective of the initial HCN concentration (mg/100gm dry matter) in Gundrijowar (Sorghum vulgare) at 15 DAS, it declined to safe level of feeding to ruminant animals at $25 \%$ flowering stage.

\section{Acknowledgments}

Authors thank the University authorities, Research scientist and Head, Cattle Breeding farm, Professor \& Head, Department of Agriculture Chemistry \& Soil Science, Junagadh agricultural University, Junagadh, Gujarat for facilities provided and cooperation extended for this work.

\section{References}

AOAC. (1995). Official Methods of Analysis. 16th Edn., Association of Official Analytical Chemists, Washington, DC., USA.

Carlson, M.P and Anderson, B. (2013). Cyanide poisoning.

Chaturvedi, V.K., Devender, V and Kandalikar, S.S. (1994). Hydrocyanic acid content in released hybrids, varieties and parental line of grain sorghum (Sorghum bicolor) at two growth stages. Indian Agric. Sci., 64(4): 403-404.

Duncan, D.B. (1955). Multiple Ranges and Multiple F Test.Biometrics, 1: 1-42.

Fjell, D., Dale, B and Gene, T. (1991). Nitrate and prussic acid toxicity in forage causes, prevention and feeding management, Cooperative extension service, Kansas state university, Manhattan, Kansas, USA, pp. 1-4.

Karthika, N and Kalpana, R. (2017). HCN Content and Forage Yield of Multi-Cut Forage Sorghum under Different Organic Manures and Nitrogen Levels. 
Chemical Science Review and Letters, 6(23): 1659-1663.

Muthuswamy, P.M., Govindaswamy and Krishnamurthy, K.K. (1976). Effect of stage of cutting on the crude protein and prussic acid content of $\mathrm{CSH} 5$ sorghum. Madras Agron. J., 63(3): 200-204.

Reddy, B.V.S., Ramesh, S and Reddy, P.S. (2004). Sorghum breeding research at ICRISAT- goals, strategies, methods and accomplishments. International Sorghum and Millets Newsletter, 45: 512.

Srinivasa, D.H., Dwivedi, R.R., Govindan, R and Joshi, A. (2006). Status of hydrocyanic acid content of sorghum in relation to anthracnose caused by Collectotrichum graminicola (Ces) Wilson. Environment and Ecology, 24(3): 680-683

Snedecor, G.W and Cochran, W.G. (1994). Statistical Methods, 8th edn. Affiliated East-West press Pvt. Ltd., New Delhi, India.

Wheeler, J. L., Mulcahy, J.L., Walcott, J and Rapp, G. (1990). Factors affecting the hydrogen cyanide potential of sweet Sorghum. Australian Journal of Agricultural research. 41: 1093-1100.

\section{How to cite this article:}

Jadav, C. N., R. B. Makwana, S. S. Parikh, P. M. Gamit, K. S. Murthy and Gajabhiye, P. U. 2019. Hydrocyanic Acid (HCN) Estimation during Different Stages of Growth in Gundrijowar (Sorghum vulgare) Fodder Crop.. Int.J.Curr.Microbiol.App.Sci. 8(09): 1328-1333. doi: https://doi.org/10.20546/ijcmas.2019.809.152 